\title{
Separation performance of poly(vinyl alcohol) based nanofiltration membranes crosslinked by malic acid for salt solutions
}

- Tran Le Hai

- Van Thi My Linh

- Vuu Ngoc Duy Minh

- Mai Thanh Phong*

Ho Chi Minh city University of Technology-VNU-HCM

(Manuscript Received on April 21st, 2016, Manuscript Revised May 17th, 2016)

\section{ABSTRACT:}

In this study, poly(vinyl alcohol) (PVA) based nanofiltration (NF) membranes were prepared by coating a thin PVA film on polysulfone ultrafiltration support substrates. The PVA film was cross-linked using malic acid in the presence of $\mathrm{HCl}$ as a catalyst. The impacts of crosslinker content and PVA molecular weight on physicochemical properties and separation performance of the prepared membranes were investigated. The obtained membranes were characterized using FTIR spectra, swelling degree, and sessile drop contact angles, respectively. Then, the separation performance of the NF membrane was systematically evaluated for pure water; magnesium sulfate

Key words: nanofiltration, membrane, poly (vinyl alcohol), brackish water, desalination.

\section{INTRODUCTION}

Nanofiltration (NF) membranes, a particular category of driven-pressure
(MgSO4) as well as sodium chloride ( $\mathrm{NaCl}$ ) solutions using a custom fabricated 4-cell crossflow desalination system. On increasing the malic acid content, the extent of crosslinking degree increased and disrupted the crystallinity of the PVA film. The salt rejection of the prepared membranes was found to increase and then decrease through the maximum point of malic acid content for $20 \mathrm{wt} \%$, while the water permeability showed the opposite trend. Moreover, the results revealed that the prepared membrane with higher molecular weight exhibited lower water permeability but better salt rejection. membranes, provide the separation properties of reverse osmosis (RO) membranes and ultrafiltration (UF) membranes. Accordingly, they are favorable to the separation of hardness 
metal ions, toxic and dissolved organic molecules (>500 Da) [1-6]. NF membranes have been widely applied for desalination as well as water treatment due to its low operation pressure, high flux, good rejection of multivalent metal ions, excellent elimination of organic molecules and moderate retention of monovalent metal ions. Moreover, NF process availably offers several advantages such as low capital, operation and maintenance cost as compared with $\mathrm{RO}$ process [2].

Polyamide (PA) based NF membranes have been successful commercialized for brackish water desalination. PA membranes are fabricated through the interfacial polymerization using multifunctional amine and acyl chloride monomers. They show high water flux, good rejection multivalent ions, but low anti-fouling property, low chemical stability, and weak chlorine tolerance [1-6]. In developing countries, the high fabrication cost also is one of the obstacles restricting the application of PA based NF membranes [2]. Recently, poly(vinyl alcohol) (PVA) has been intensively used for preparing NF membranes owing to its good physical and chemical stability, low cost, commercial availability and excellent filmforming property [2-6]. The PVA-based NF membranes were mostly prepared by the chemical crosslinking reaction using multifunctional compounds, such as dialdehydes, dicarboxylic acids, and dianhydrides, which are capable of reacting with hydroxyl groups of PVA. The water permeability and salt rejection of the PVA-based NF membrane were found to depend on the variations of PVA concentration, PVA molecular weight, crosslinking agents, crosslinker concentration, porous substrate's characteristics and preparing conditions $[1,3,5,6]$. It notes that the PVA concentration in the range of 0.1-0.5 $\mathrm{wt} \%$ was capable of making NF membranes with good separation performance for brackish water desalination [1,4-6]. The multivalent salt rejection $\left(\mathrm{MgSO}_{4}\right)$ and monovalent salt retention $(\mathrm{NaCl})$ were approximately $70-85 \%$ and $15-$ $35 \%$, respectively, while the water permeability was from 2 to $10 \mathrm{mPa}^{-1} \mathrm{~s}^{-1} \times 10^{-12}\left(8-43 \mathrm{~L}^{-m^{2}} \mathrm{~h}\right)$ [1]. Additionally, the PVA molecular weight $\left(\mathrm{M}_{\mathrm{w}}\right)$ in the range of $27-100 \mathrm{kDa}$ was used for making NF membranes. Although the higher $\mathrm{M}_{\mathrm{w}}$ showed, the more stability of the PVA membranes in aqueous solution during NF process, the PVA membranes made by $\mathrm{M}_{\mathrm{w}}$ from $27 \mathrm{kDa}$ to $61 \mathrm{kDa}$ exhibited high water permeability [1,3-6]. Previous studies demonstrated that malic acid, a dicarboxylic acid with an additional hydroxyl group in its molecule, was a good crosslinking agent for making PVA membranes [1,4-6]. The PVA membranes crosslinked by malic acid exhibited not only good chemical stability and separation performance but also high anti-fouling property $[1,6]$.

This work focuses on the preparation of PVA based NF membranes by coating a crosslinked PVA thin film on the surface of polysulfone ultrafiltration (UF) substrates. The PVA thin film was crosslinked by malic acid in the presence of $\mathrm{HCl}$ as a catalyst. The effects of malic acid content and PVA molecular weight on the physicochemical properties water permeability and salt rejection of the prepared membranes were systematically investigated and thoroughly discussed. 


\section{EXPERIMENTAL}

\subsection{Chemicals and materials}

PVA powders $\left(\mathrm{M}_{\mathrm{w}} 31 \mathrm{kDa}\right.$ and $\left.\mathrm{M}_{\mathrm{w}} 61 \mathrm{kDa}\right)$ were purchased from Sigma-Aldrich. Malic acid $\left(\mathrm{C}_{4} \mathrm{H}_{6} \mathrm{O}_{5}\right)$ with the purity of $99 \%$ received from Merck was used as crosslinking agent. The commercial UF membrane (PS20-Dow-filmtec) was utilized as the supporting substrate where the crosslinked PVA film was coated. $\mathrm{HCl}(35 \%)$ was received from Merck.

\subsection{Membrane preparation}

PVA solutions with a concentration of 0.1 $\mathrm{wt} / \mathrm{v} \%$ were prepared by dissolving PVA in deionized (DI) water at $90^{\circ} \mathrm{C}$ under constant stirring for $2 \mathrm{~h}$. Next, PVA solutions were cooled to room temperature and then, crosslinking agent malic acid was added along with $2 \mathrm{M} \mathrm{HCl}$ as catalyst under continuous stirring to produce the coating solution. The content of malic acid was varied according to the crosslinker per PVA weight ratio of $5 \mathrm{wt} \%$ to $60 \mathrm{wt} \%$. The supporting substrate was taped onto the glass plate, and only the membrane surface side was contacted with PVA solution in dip coating process. PVA solution was coated onto supporting membrane for $10 \mathrm{~min}$. The PVA coated membrane was dried at the ambient temperature for $24 \mathrm{~h}$. The obtained membrane was immersed into the same PVA solution again for $10 \mathrm{~s}$ and dried in air for $24 \mathrm{~h}$. Finally, the obtained membrane was cured at $100^{\circ} \mathrm{C}$ for $1 \mathrm{~h}$ to accelerate the crosslinking reaction in PVA film [3].

\subsection{Membrane characterization and separation performance}

The derived membranes were characterized by using a Bruker FTIR spectrometer. Three replicate FTIR spectra were obtained for each membrane type, with each spectrum averaged from 100 scans collected from 400 to $4000 \mathrm{~cm}^{-1}$ at $4 \mathrm{~cm}^{-1}$ increments. Pure water contact angles were determined from measured sessile drop contact angles on membranes using the contact angle goniometer. Six equilibrium contact angles were measured for each sample.

For swelling experiments, the pieces of dried membranes with the dimension of $3 \times 3 \mathrm{~cm}$ were immersed in pure water at $30^{\circ} \mathrm{C}$ for $48 \mathrm{~h}$ to reach equilibrium swelling. The swollen membranes were wiped carefully using tissue paper for removing residual solution on the membrane surfaces. Then, the swollen membranes were weighted by a mass balance (accuracy $\pm 0.0001 \mathrm{~g}$ ). The degree of swelling was defined as

Swelling degree $(\%)=\frac{W_{S}-W_{D}}{W_{D}} \times 100$

Wherein, $\mathrm{W}_{\mathrm{S}}(\mathrm{g})$ and $\mathrm{W}_{\mathrm{D}}(\mathrm{g})$ were the mass of the swollen membrane and the mass of the dried membrane, respectively. The data of swelling degree were collected from three replicate experiments.

Brackish water desalination experiments were carried out by using a custom fabricated bench-scale crossflow RO desalination simulator. Four plate-and-frame membrane modules were designed with an individual membrane area of $21 \mathrm{~cm}^{2}$. Water was maintained well mixed in the feed tank by magnetic stirring. The feedwater was pressurized by a highpressure pump (Catpump, USA) with a steady feed flow of $0.12 \mathrm{gpm}$. The temperature of feedwater was maintained at $25 \pm 0.5{ }^{\circ} \mathrm{C}$ by a custom fabricated chiller. All permeate and concentrate were returned to the feed tank to avoid concentrating the electrolyte in the system.

\section{Trang 72}


First, DI water was filtered through the membranes at $350 \mathrm{psi}$ for at least $12 \mathrm{~h}$. After achieving stable flux, the permeability of membrane was determined by measuring the water flux at an applied pressure of 300 psi. Second, the $\mathrm{MgSO}_{4}$ solutions at a fixed concentration were filtered through the membranes at 300 psi. The permeate flow rate and conductivity of feed and permeate samples were collected after the system performance was stable for at least $2 \mathrm{~h}$. Next, the separation of $\mathrm{NaCl}$ solutions was carried out as filtering $\mathrm{MgSO}_{4}$ solutions. The permeate flow rate and conductivity were indicated using a mass balance (AWS-602, USA) and a conductivity meter (Hach-Sension 378). The data of flux and salt rejection reported in this paper were based on the average of four experimental runs. Water flux was determined from permeate water flow rate as

$$
\mathrm{J}_{\mathrm{w}}=\frac{\mathrm{Q}_{\mathrm{p}}}{\mathrm{A}_{\mathrm{m}}}\left(\mathrm{L} / \mathrm{m}^{2} \mathrm{~h}\right)
$$

Where $Q_{p}$ was the permeate water flow rate and $A_{m}$ was the effective membrane area. The water permeability of the prepared membranes was determined as

$$
J_{w}=A(\Delta P-\Delta \pi)
$$

Wherein, A was the water permeability, $\Delta \mathrm{P}$ was the operational pressure and $\Delta \pi$ was the osmotic pressure of the salt solution. Feed and permeate conductivities were used to calculate the observed salt rejection using the following equation

$$
X_{s}=1-\left(\frac{k_{P}}{k_{f}}\right)
$$

Where $\mathrm{k}_{\mathrm{f}}$ and $\mathrm{k}_{\mathrm{p}}$ were the feed and permeate conductivity

\section{RESULTS AND DISCUSSION}

\subsection{Effect of malic acid content on separation performance of prepared NF membrane}

The FTIR spectra of the prepared membrane was presented in Fig. 1. The peaks 3200 - $3600 \mathrm{~cm}^{-1}$ assigned to hydroxyl band ($\mathrm{OH})$ in the PVA thin film. The peaks at $1725 \mathrm{~cm}^{-}$ ${ }^{1}$ and $1094 \mathrm{~cm}^{-1}$ represented the $-\mathrm{C}=\mathrm{O}-$ and $-\mathrm{C}$ $\mathrm{O}$ - stretches in $-\mathrm{C}=\mathrm{O}-\mathrm{O}-\mathrm{C}-$, which reflected the crosslinking bonds. The FTIR spectra were evidence of crosslinking reactions between the hydroxyl groups of PVA and the carboxylic groups of malic acid in the PVA film. [3-5].

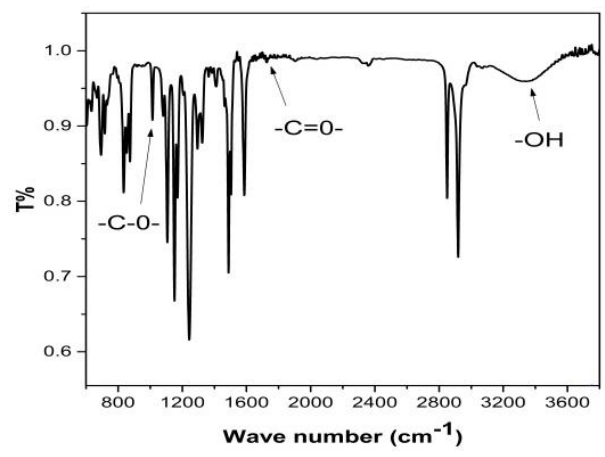

Figure 1. FTIR spectra of PVA membranes crosslinked with different malic acid content

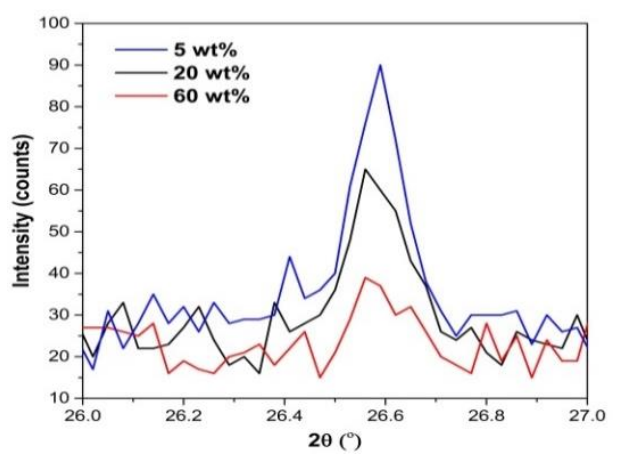

Figure 2. XRD spectra of PVA membranes crosslinked with different malic acid content

The extent of crosslinking was demonstrated to change the crystallinity of the PVA films, which affected the water permeability and salt rejection of the PVA 
membranes [5,6]. It was obviously acknowledged that semi-crystalline PVA had the impermeable crystalline region and the permeable amorphous matrix [1,3-6]. The crystal structure, forming from hydrogen linkage, depleted both the sorption sites and the mobility of the polymer chains, which allowed the high transport of solvent and solute molecules through the membrane [1,3-6]. Meanwhile, the polymer chains in the amorphous structure were much more mobile and thus, the mass transfer of water and solute molecules throughout the membrane was promoted. The XRD spectra described the crystallinity of the prepared membranes were shown in Fig. 2. It revealed that the crystalline peak (at $2 \theta=26.6^{\circ}$ ) was reduced with the increase in malic acid content. Moreover, at higher malic acid content (>20 wt\%) the crystalline peak was observed to destroy mostly and separate into two small peaks. The decrease in the crystalline peak implied that crosslinking reaction disrupted the crystallinity and induced the increase in the amorphous fraction of the PVA film. The decrease in the crystallinity of the PVA film might be due to the incomplete crosslinking reaction, resulting in the addtion of large carboxylic acid moieties in the PVA film. Moreover, the large molecular network with high degree of crosslinking was also contributed to inhibited the chain segment motion for crystallization in the PVA film.

Fig. 3 showed the effects of the malic acid content on the water contact angle and swelling degree of the prepared membranes. The swelling degree was observed to reduce significantly when raising the malic acid content from $5 \mathrm{wt} \%$ to $20 \mathrm{wt} \%$, and go up as increasing the malic acid content above $20 \mathrm{wt} \%$. The water contact angle indicated the hydrophilic property of the membrane surface. The higher water contact angle signified the lower hydrophilicity of the membrane surface. The water contact angle was found to rise as increasing malic acid content. On increasing the crosslinker content, much more hydroxyl groups in the PVA matrix reacted with carboxylic groups on the malic acid to produce the ester crosslinking linkages [1,3-7]. Thus, the increase of the crosslinking density resulted in the decrease of hydrophilicity of the membrane surface.

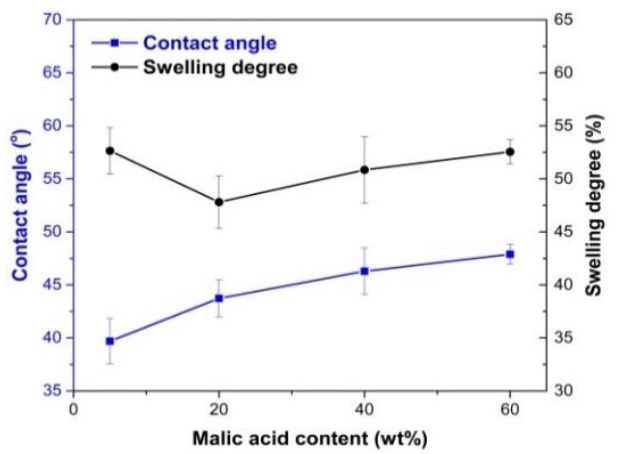

Figure 3. Contact angle and swelling degree of PVA membranes crosslinked with different malic acid content

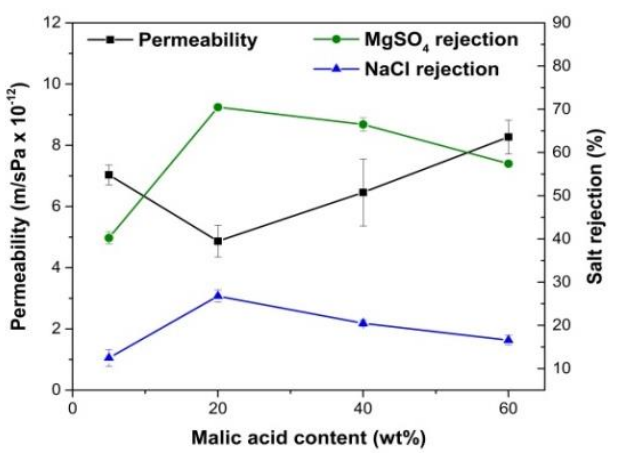

Figure 4. Effects of malic acid content on the separation performance of prepared PVAbased NF membranes

The water permeability and solute rejection of the PVA-based membranes were evaluated using pure water and salt solution of $\mathrm{MgSO}_{4}$ and

\section{Trang 74}


$\mathrm{NaCl}$ for $2 \mathrm{~g} / \mathrm{L}$ (Fig. 4). The water permeability of the prepared membranes decreased with malic acid content increasing from $5 \mathrm{wt} \%$ to $20 \mathrm{wt} \%$, and then increased when increasing malic acid content above $20 \mathrm{wt} \%$. Meanwhile, solute rejection presented the opposite trend. Salt rejection of the prepared membranes increased and then decreased with the malic acid content of $20 \mathrm{wt} \%$. From the results, it was suggested that both the hydrophilic and crystallinity affected the separation performance of the prepared membranes. At lower crosslinker content $(<20$ $w t \%)$, the crystallinity of the resulting membrane was not completely demolished, while the hydrophilic property was declined. The reduction in hydrophilicity dominantly diminished the affinity between the water molecules and membrane surface. Therefore, the permeability was reduced, but the salt rejection of the prepared membranes was improved. However, at higher crosslinking agent content (>20 wt $\%$ ), the disruption of the crystalline regions in the PVA membrane was superior. The more amorphous fractions were formed in the PVA membrane, promoting the higher permeability and transport of the water and salt molecules through the resulting membranes. Accordingly, the crosslinked PVA membranes had higher water permeability but lower salt rejection as increasing the malic acid content above $20 \mathrm{wt} \%$.

\subsection{Effect of PVA molecular weight on the} separation performance of NF membranes

For investigating the effect of PVA molecular weight on the separation performance of the prepared NF membranes, two PVA with the different molecular weight of $61 \mathrm{kDa}$ and 31 $\mathrm{kDa}$ were used. The PVA concentration and the malic acid content in the coating solution were fixed at $0.1 \mathrm{wt} \%$ and $20 \mathrm{wt} \%$, respectively. The XRD spectra presented the crystallinity of the prepared membranes were shown in Fig. 5. It was observed that the NF membrane made from PVA molecular of $31 \mathrm{kDa}$ had the intensity of crystalline peak (at $2 \theta=26.6^{\circ}$ ) lower than that made from PVA molecular of $61 \mathrm{kDa}$. It indicated that the $31 \mathrm{kDa}$ PVA membrane had much more amorphous regions than the $61 \mathrm{kDa}$ PVA membrane.

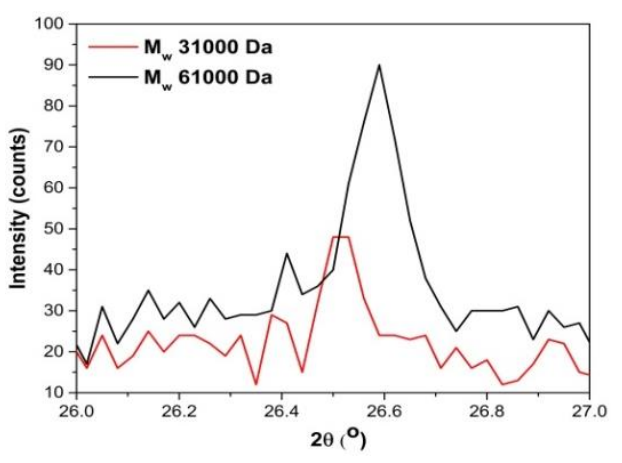

Figure 5. XRD spectra of cross-linked PVA-based NF membranes prepared by different PVA $\mathrm{M}_{\mathrm{w}}$

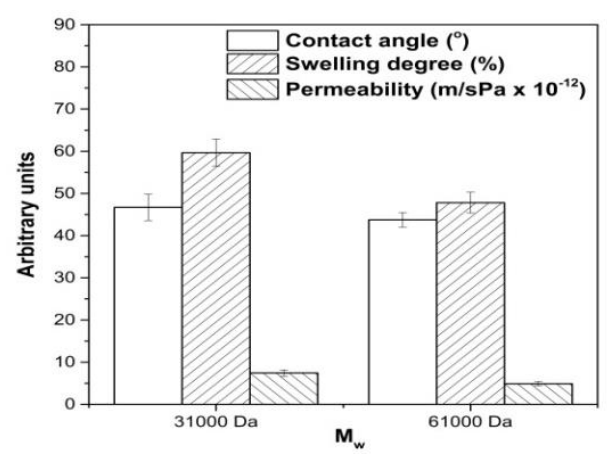

Figure 6. Contact angle, swelling degree and permeability of membranes developed by various PVA $\mathrm{M}_{\mathrm{w}}$

The pure water contact angle, swelling degree and water permeability of the crosslinked PVA-based NF membranes were presented in Fig. 6. It was found that the NF 
membrane prepared by PVA molecular weight of $61 \mathrm{kDa}$ had lower hydrophilic property, swelling degree and water permeability as compared with that made by PVA molecular weight of $31 \mathrm{kDa}$. Meanwhile, the $\mathrm{MgSO}_{4}$ and $\mathrm{NaCl}$ rejection of 61 $\mathrm{kDa}$ PVA membrane was double as compared to $31 \mathrm{kDa}$ PVA membrane (Fig. 7). It could be explained by XRD results that the NF membrane formed by PVA molecular of $31 \mathrm{kDa}$ possessed higher amorphous fractions than that formed by $61 \mathrm{kDa}$. In the amorphous regions, the PVA chain network was more flexible resulting in the easy penetration and diffusion of the species, like water and solute molecules in the PVA membrane. As a result, the membrane made from PVA molecular of $31 \mathrm{kDa}$ exhibited higher permeability but lower salt rejection than that made from PVA molecular of $61 \mathrm{kDa}$.

The crosslinked PVA-based NF membrane synthesized with $61 \mathrm{kDa}$ PVA concentration of $0.1 \mathrm{wt} \%$, the malic acid content of $20 \mathrm{wt} \%$ was utilized to evaluate the separation performance for salt solutions with different concentration from 0.5 to $15 \mathrm{~g} / \mathrm{L}$. The results of water permeability, $\mathrm{MgSO}_{4}$ rejection and $\mathrm{NaCl}$ rejection of the prepared membrane were shown in Fig. 8. It described that the water permeability was slightly reduced from 5.0 to $4.2 \times 10^{-12} \mathrm{mPa}^{-}$ ${ }^{1} \mathrm{~S}^{-1}$ and the salt rejection was also decreased with the increase of salt concentration in the range of 0.5-15 g/L. In particular, the retention of $\mathrm{MgSO}_{4}$ was decreased approximately from $73 \%$ to $62 \%$ and the rejection of $\mathrm{NaCl}$ was reduced from $39 \%$ to $16 \%$, respectively.

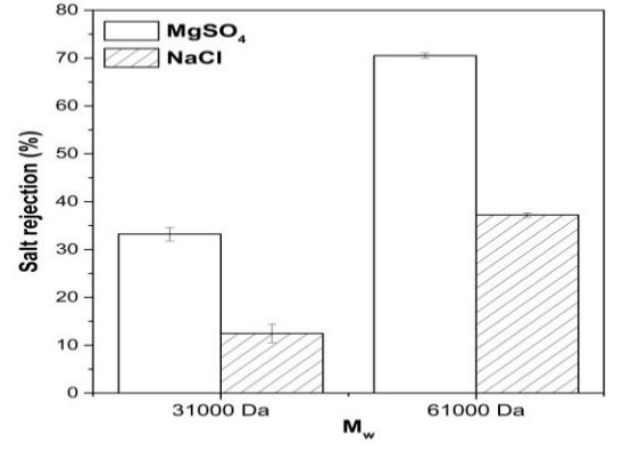

Fig 7. Effects of PVA $\mathrm{M}_{\mathrm{w}}$ on the separation performance of prepared NF membranes

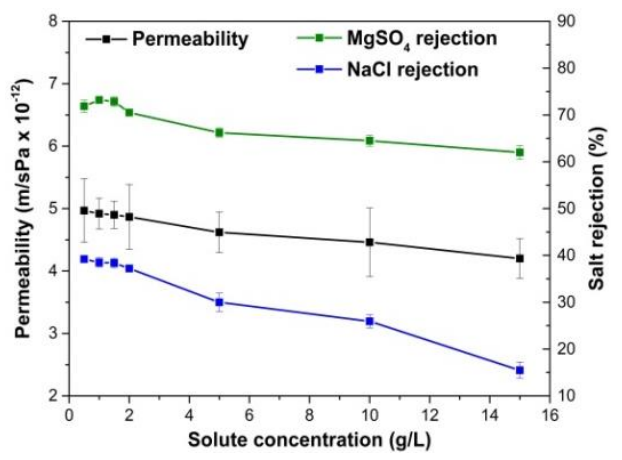

Fig 8. Water permeability and salt rejection of $61 \mathrm{kDa}$ PVA-based NF membrane

\section{CONCLUSIONS}

Poly(vinyl alcohol) (PVA) based composite nanofiltration (NF) membranes were prepared by coating a thin PVA film on polysulfone ultrafiltration support substrates. The PVA film was crosslinked using malic acid in the presence of $\mathrm{HCl}$ as a catalyst. The results indicated that the malic acid content and PVA molecular weight affected the hydrophilicity and crystallinity of the resulting membranes. In little malic acid content $\quad(<20 \mathrm{wt} \%)$, the reduction of hydrophilicity was favorable but at higher malic acid content the decline of crystallinity was more dominant in the changes of water permeability of the prepared membranes. Moreover, the higher 
PVA molecular weight gave better salt rejection for the PVA-based NF membrane, although the permeability was observed to decreased. The PVA molecular weight of $61 \mathrm{kDa}$ and malic acid content of $20 \mathrm{wt} \%$ were suitable for making the crosslinked PVA-based NF membranes with good retention of $\mathrm{MgSO}_{4}$ and $\mathrm{NaCl}$ solutions in the range of $0.5-2 \mathrm{~g} / \mathrm{L}$.
Acknowledgement. The authors gratefully acknowledge the Ho Chi Minh city University of Technology - VNU-HCM, for financial support under Grant T-KTHH-2015-75.

\section{Khả năng phân tách muối của màng lọc nano trên nền poly(vinyl alcohol) được nối mạng bởi axít malic}

- Trần Lê Hải

- Văn Thị Mỹ Linh

- Vưu Ngọc Duy Minh

- Mai Thanh Phong*

Trường Đại Học Bách Khoa - ĐHQG HCM

\section{TÓM TẮT:}

Trong nghiên cúu này, màng lọc nano (NF) trên co sở vật liệu poly (vinyl alcohol) (PVA) được chế tạo bằng cách phủ một lóp màng PVA lên lớp đõ màng siêu loc polysulfone. Lớp màng PVA được nối mạng bởi axit malic với xúc tác $H C l$. Anh hương của nồng độ chất nối mạng axit malic và khối lượng phân tử PVA lên các đặc tính lý hóa và hoạt động phân tách của màng tạo thành đã được khảo sát. Màng đã chế tạo được đánh giá bởi phổ FTIR, tính truơng nở và phuoong pháp đo góc tiếp xúc với nước cất. Hoạt động phân tách của màng $N F$ đuợc đánh giá bởi quá trình lọ nuớc tinh khiết, dung dịch muối MgSO4 và muối $\mathrm{NaCl}$ bằng hệ thống lọc muối dạng dòng chảy bang ngang qua màng. Khi tăng nồng độ axit malic, mật độ nối mạng của màng tăng và phá võ độ tinh thể hóa của màng PVA. Độ lọc muối của màng tăng và giảm qua nồng độ axit malic $20 \%$ kl, nhung độ thẩm thấu nuớc của màng thể hiện xu huớng nuớc lại. Ngoài ra, kết 
quả cho thấy, màng tạo thành với khối luợng phân tư PVA cao hơn thể hiện độ thẩm thấu nuớc thấp, nhung lại cho độ lọc muối tốt hơn so với màng tạo thành tù khối luợng phân tử PVA thấp.

Tù khóa: lọc nano, màng lọc, polyvinyl alcohol, nuơóc lọ, lọc muối.

\section{REFERENCES}

[1] Brian Bolto, Thuy Tran, Manh Hoang, Zhongli Xie, Crosslinked poly(vinyl alcohol) membranes, Progress in Polymer Science 34 (2009), 969-981.

[2] Dong Zhou, Lijing Zhu, Yinyi Fu, Minghe Zhu, Lixin Xue. - Development of lower cost seawater desalination processes using nanofiltration technologies - A Review, Desalination 376 (2015), 109-116.

[3] A.L. Ahmad, N.M. Yusuf, B.S. Ooi. Preparation and modification of poly(vinyl alcohol) membrane: Effect of crosslinking time towards its morphology, Desalination 287 (2012), 35-40.

[4] J.M. Gohil, Bhattacharya, P. Ray, - Study on the Crosslinking of poly(Vinyl Alcohol), Journal of Polymer Research 13 (2016), 161-169.

[5] Golhil J. M., Ray P., Polyvinyl alcohol as the barrier layer in thin film composite nanofiltration membrane: Preparation, characterization, and performance evaluation, Journal of Colloid and Interface Science 338 (2009) 121-127

[6] Fubing Peng, Zhongyi Jiang, Hoek V. E. M. Tuning the molecular structure, separation performance and interfacial properties of poly (vinyl alcohol)-polysulfone interfacial composite membranes, J. Membr. Sci. 368 (2011) 26-33. 